УдК 616-089+616.381-002

DOI 10.11603/2414-4533.2020.1.10732

СМ. М. ДРОНЯК, І. М. ШЕВЧУК, В. М. ДРОНЯК, О. Я. ПОПАДЮК

Івано-Франківський національний медичний університет

\title{
Прогнозування перебігу післяопераційного перитоніту
}

\begin{abstract}
Мета роботи: розпрацювати шкалу прогнозування ризику розвитку післяопераційного перитоніту.
Матеріали і методи. У роботі проаналізовано 244 випадки післяопераційного перитоніту (ПП), прооперованих у відділенні хірургії Івано-Франківської обласної лікарні протягом 2010-2019 рр. Супутні захворювання виявлено у 176 (72,1 \%) хворих. Незначно переважали хворі чоловічої статі - 138 (56,6 \%). Вік пацієнтів був у межах $18-88$ років (медіана - 61 р.). За тяжкістю стану більшість хворих (147 осіб (60,2 \%)) - протягом 1-4 діб після операції (медіана - 2 доби) перебували у відділенні реанімації та інтенсивної терапії. Перитоніт був місцевим відмежованим у 125 (51,2 \%), розлитим - у 119 (48,8 \%) хворих. Післяопераційні ускладнення розвинулись у 74 випадках (30,3%) і були гнійно-септичними у 75 \%.

Результати досліджень та їх обговорення. Зважаючи на результати наших досліджень, для визначення тяжкості перебігу післяопераційного перитоніту в якості предикторів пропонуємо наступні показники: вік хворого понад 60 років, кількість лейкоцитів у периферичній крові понад $12 \times 10^{9}$ г/л, рівень С-реактивного білка в сироватці крові понад 10 мг/л, активність лужної фосфатази понад 1400 нмоль/л-с, вміст дієнових кон'югат понад 2,5 од. оптичної щільності, вміст малонового діальдегіду понад 5 нмоль/мл, рівень молекул середньої маси понад 0,350 ум. од. Значення СРБ, що перевищують 5 мг/л, є несприятливою прогностичною ознакою, при легкому перебізі ПП перевищення цього рівня було у 42 (30,9 \%) із 136 хворих, а при тяжкому - у 98 (90,7 \%) із 108 хворих.

При позитивних чотирьох і більше критеріях був імовірний тяжкий перебіг ПП. Враховуючи результати проведених досліджень, для визначення тяжкості перебігу післяопераційного перитоніту ми запропонували робочу систему прогнозування перебігу ПП. Попередня апробація цієї системи показників підтвердила її чутливість 71,2%, а специфічність 81,4 \%.
\end{abstract}

Ключові слова: абдомінальний сепсис; післяопераційний перитоніт; прогнозування перебігу.

Постановка проблеми і аналіз останніх досліджень та публікацій. Більшість застосовуваних на сьогодні прогностичних індексів покликана оцінити тяжкість стану та / або імовірність летального наслідку у хворих із післяопераційним перитонітом (ПП). Частина із них є концептуально близькими до пропонованого нами, однак для прогнозування ризику розвитку ПП вони використаними бути не можуть.

Наприклад, спосіб прогнозування розвитку післяопераційного перитоніту при гострій абдомінальній патології побудовано на аналізі даних шкали АРАСНЕ-2, окремих діагностичних, клінічних та інтраопераційних показників [5]. Його перевагою вважають можливість встановити показання до повного закриття черевної порожнини ще до завершення операційного втручання. Проте ця прогностична шкала побудована на неактуальній номенклатурі сепсису та дещо застарілій версії шкали APACHЕ, вміщає показники, оцінка яких основана на суб'єктивній думці (наприклад, активність перистальтики). Цей спосіб розпрацьовано для прогнозу післяопераційного перитоніту, зумовленого неспроможністю швів анастомозу, перфорацією гострої виразки або некротичної ділянки кишки тощо.

Іншими клініцистами запропоновано спосіб визначення тяжкості гострого перитоніту та прогнозування його перебігу у післяопераційному періоді [1]. На основі періодичного визначення в крові кількості лейкоцитів, паличкоядерних нейтрофілів та рівнів рецепції ІЛ-1 та ІЛ-2 сироватки крові, автори бальним методом оцінювали тяжкість стану хворого. Цей спосіб, незважаючи на тяжкість стану хворого з гострим перитонітом, не вміщає цілого ряду імунних, клінічних та, особливо, гормональних факторів гомеостазу, принципових для оцінки абдомінального сепсису (AC) та прогнозу його перебігу. Результати, отримані при використанні ціє шкали, мають радше описовий характер тяжкості стану, не встановлюючи показань до зміни тактики.

Близьким до пропонованого нами є спосіб прогнозування перебігу гострого перитоніту та визначення показань до виконання програмованих санацій черевної порожнини [3], проте у випадку ПП релапаротомії не завжди обирають як провідний метод лікування.

На сьогодні у клінічному використанні $є$ чимало шкал, покликаних прогнозувати ризик розвитку ПП, його ускладнень та летального наслідку: MIP, qSOFA, SAPS-2, P-POSSUM, PIA-2 та ін. [2, $4,6,7]$. У відношенні післяопераційного перитоніту ці шкали малозастосовні, оскільки не володіють специфічністю до нього та не здатні ефективно його прогнозувати, залишаючи проблему недостатньо вивченою.

Мета роботи: розпрацювати шкалу прогнозування ризику розвитку ПП. 
Матеріали і методи. Нами проаналізовано 244 випадки ПП, прооперованих у відділенні хірургії Івано-Франківської обласної лікарні протягом 2010-2019 рр. Супутні захворювання виявлено у 176 (72,1 \%) хворих. Незначно переважали хворі чоловічої статі - 138 (56,6 \%). Вік пацієнтів був у межах 18-88 років (медіана - 61 р.). За тяжкістю стану більшість хворих (147 осіб (60,2 \%)) - протягом 1-4 діб після операції (медіана - 2 доби) перебували у відділенні реанімації та інтенсивної терапії (BPIT). Перитоніт був місцевим відмежованим у 125 (51,2 \%), розлитим - у 119 (48,8 \%) хворих. Післяопераційні ускладнення розвинулись у 74 випадках (30,3 \%) і були гнійносептичними у $75 \%$. Післяопераційний перитоніт мав летальний наслідок у 45 (18,4 \%) випадках. Основною причиною смерті став сепсис. Для визначення зв'язку між якісними характеристиками використано точний критерій Фішера у разі таблиць $2 \times 2$ і критерій $x 2$ Пірсона - для більших таблиць. Показники, які увійшли у шкалу прогнозування, статистично опрацьовано з застосуванням пакету програм STATISTICA (StatSoft Inc., USA).

Результати досліджень та їх обговорення. Легкий перебіг ПП діагностовано у 98 (52,7 \%) із 186 хворих до 60 років, тяжкий - у 27 (46,5 \%) із 58 хворих у віці 60 і більше років. На перший погляд різниця у вікових групах за тяжкістю перебігу незначна. Проте 29 (64,4 \%) із 45 хворих, які померли, мали вік понад 60 років, тому цей критерій мав більш вагоме значення саме у хворих на ПП.

При госпіталізації рівень лейкоцитів у периферичній крові був вищим у хворих з тяжким перебігом ПП, ніж у хворих з легким перебігом захворювання і становив в середньому $11,4 \pm 0,89$ і $8,7 \pm 0,84$ відповідно (p<0,05). У хворих з ПП кількість лейкоцитів становила в середньому $10,7 \pm 0,95 \times 10^{9}$ г/л, тоді як у хворих з гострим перфоративним перитонітом - 9,8 $\pm 0,91$ х10 г/л ( $>>0,05)$. 3 першого погляду різниця невелика, проте при детальному аналізі виявлено, що при тяжкому перебізі захворювання кількість лейкоцитів у периферичній крові була понад $12 \times 10^{9}$ г/л у 132 (54 \%) із 244 хворих на ПП, тоді як така кількість лейкоцитів спостерігалась тільки у 68 (32,1 \%) із 212 хворих на гострий перфоративний перитоніт. Тому цей показник ми вважаємо більш специфічним для хворих на ПП.

Рівень вмісту С-реактивного білка (СРБ) $є$ неспецифічною реакцією на запальні та інфекційні процеси. У нормі рівень СРБ у сироватці крові нижче 1-5 мг/л. При успішному лікуванні він знижується, нормалізуючись на 6-10-ту добу хвороби, що дозволяє використовувати цей тест для спостереження за перебігом захворювання та контролю ефективності лікування. У хворих з ПП рівень СРБ підвищується на 1-й день захворювання і до кінця 2-го - початку 3-го тижня знижується до нормальних значень. Значення СРБ, що перевищують 5 мг/л, є несприятливою прогностичною ознакою, пов'язаною з ризиком розвитку ускладнень ПП, зокрема, абдомінального сепсису. Вважаючи за точку відліку вміст СРБ 10 мг/л, ми отримали наступні результати: при легкому перебізі ПП перевищення цього рівня було у 42 (30,9 \%) із 136 хворих, а при тяжкому - у 98 (90,7 \%) із 108 хворих.

Активність лужної фосфатази перевищувала норму у 37 (15,1 \%) хворих із 244 обстежених при госпіталізації. Вважаючи за точку відліку активність лужної фосфатази понад 1200 нмоль/с-л (в нормі - чоловіки 900-2290 нмоль/с-л, жінки 740-1200 нмоль/с-л), ми отримали перевищення цього рівня у 28 (75,7 \%) із 37 хворих на ПП.

3 інтенсифікацією ПОЛ пов’язують перехід місцевого запального процесу на системний рівень. Тому чим вища активність ПОЛ, тим більш імовірний тяжкий перебіг захворювання. Стан ПОЛ оцінювали шляхом визначення ДК та МДА. Вважаючи за точку відліку концентрацію ДК понад 2,5 од. опт. щільності чутливість показника становила 89,5 \%, специфічність - 91,4 \%. Слід відмітити, що концентрацію ДК понад 2,5 од. опт. щільності діагностовано у 96 (88,9 \%) із 108 хворих на ПП з тяжким перебігом, тоді як у хворих на ПП з легким перебігом така концентрація була тільки у 31 (25,7\%) із 136 хворих.

При концентрації МДА понад 5 нмоль/мл чутливість його становила 86,7 \%, специфічність 89,2 \% (табл. 1). Така концентрація спостерігалась у 46 (42,6 \%) з 108 хворих з тяжким перебігом ПП і тільки у 35 (25,7 \%) з 136 хворих на ПП з легким перебігом.

Для прогнозування тяжкості перебігу ГП, ускладненого синдромом жовтяниці, найбільш інформативним було визначення концентрації молекул середньої маси (МСМ). Вважаючи за точку відліку рівень 0,350 ум. од. ми отримали чутливість МСМ 76,4 \%, а специфічність 81,7 \%. Тільки у 31 (22,8 \%) з 136 хворих на ПП з легким перебігом рівень МСМ перевищував 0,350 ум. од., тоді як у хворих на ПП з тяжким перебігом МСМ сягали такої концентрації у 76 (70,4%) з 108 хворих.

Отже, чутливість та специфічність ДК і МДА, а також МСМ достатньо високі (табл. 1) і можуть бути застосовані для прогнозу післяопераційного перитоніту.

Зважаючи на результати наших досліджень, для визначення тяжкості перебігу післяопераційного перитоніту в якості предикторів пропонуємо наступні показники: 
Таблиця 1. Порівняльна оцінка показників у прогнозуванні тяжкості перебігу гострого панкреатиту у хворих на післяопераційний перитоніт

\begin{tabular}{|c|c|c|c|c|}
\hline Параметри & $\begin{array}{c}\text { ДК } \\
\text { (>2,5 од. опт. щільн.) }\end{array}$ & $\begin{array}{c}\text { МДА } \\
(>5,0 \text { нмоль/мЛ) }\end{array}$ & $\begin{array}{c}\text { МСМ } \\
(>0,350 \text { ум. од) }\end{array}$ & $\begin{array}{c}\text { C-реактивний білок } \\
\text { (>10 мг/л) }\end{array}$ \\
\hline Чутливість (\%) & 89,5 & 86,7 & 76,43 & 81,2 \\
\hline $\begin{array}{l}\text { Позитивна прогностична } \\
\text { цінність, (\%) }\end{array}$ & 76,2 & 75,4 & 63,2 & 77,4 \\
\hline Специфічність, (\%) & 91,4 & 89,2 & 81,7 & 93,1 \\
\hline $\begin{array}{l}\text { Від’ємна прогностична } \\
\text { цінність, (\%) }\end{array}$ & 72,3 & 71,8 & 68,8 & 73,6 \\
\hline Ефективність (\%) & 74,3 & 73,1 & 61,6 & 75,2 \\
\hline
\end{tabular}

Вік хворого понад 60 років.

Кількість лейкоцитів у периферичній крові понад $12 \times 10^{9}$ г/л.

Рівень С-реактивного білка в сироватці крові понад 10 мг/л.

Активність лужної фосфатази понад 1400 нмоль/Л-С.

Вміст ДК понад 2,5 од. оптичної щільності.

Вміст МДА понад 5 нмоль/мл.

Рівень МСМ понад 0,350 ум. од.

При позитивних чотирьох і більше критеріях був імовірний тяжкий перебіг ПП.

Таким чином, об'єктивними критеріями діагностики хворих із гострим панкреатитом, ускладненим синдромом жовтяниці, є клінічні прояви, характер і вираженість змін у загальноклінічних і лабораторних показниках, а також результа-

\section{СПИСОК ЛІТЕРАТУРИ}

1. Complicated intra-abdominal infections in a worldwide context: an observational prospective study (CIAOW Study) / M. Sartelli, F. Catena, L. Ansaloni [et al.] // World Journal of Emergency Surgery. - 2013. - Vol. 8. - R. 1.

2. Daniel R. Surviving the first hours in sepsis: getting the basics right (an intensivist's perspective) / R. Daniel // Journal of Antimicrobials and Chemotherapy. - 2011. - Vol. 66, No. 2. - P. 11-23.

3. Evaluation of prognosis in patients with perforation peritonitis using Mannheims peritonitis index / T. Dani, L. Ramachandra, R. Nair, D. Sharma // International Journal of Scientific and Research Publications. - 2015. - Vol. 5, No. 5. - P. 1-35.

4. Kamble R. S. Prognostic factors in perforative peritonitis:

\section{REFERENCES}

1. Sartelli, M., Catena, F., Ansaloni, L., Moore, E., Malangoni, M., Velmahos, G., \& Ishii, W. (2013). Complicated intra-abdominal infections in a worldwide context: an observational prospective study (CIAOW Study). World Journal of Emergency Surgery, 8, R1. ти об’єктивного обстеження. При прогнозуванні перебігу ПП найвагоміше значення мав рівень молекул середньої маси та продуктів перекисного окислення ліпідів, які найбільше корелювали 3 тяжкістю захворювання.

Висновок. Враховуючи результати проведених досліджень, для визначення тяжкості перебігу післяопераційного перитоніту ми запропонували робочу систему прогнозування перебігу ПП, яка полягала у враховуванні віку хворого, кількості лейкоцитів, рівня білірубіну, лужної фосфатази, ПОЛ (МДА, ДК), ПСММ. На основі проведеного аналізу доведено, що ці показники найбільш ефективні при прогнозуванні саме ПП. Попередня апробація цієї системи показників ствердила її чутливість 71,2 \%, а специфічність 81,4 \%.

an observational study / R. S. Kamble, M. Singh, Y. Jaiswal // International Surgical Journal. - 2016. - Vol. 3 (3). - P. 10821092.

5. Kibe S. Diagnostic and prognostic biomarkers of sepsis in critical care / S. Kibe, K. Adams, G. Barlow // Journal of Antimicrobials and Chemotherapy. - 2011. - Vol. 66. - P. 33-40. 6. Матвійчук О. Б. Прогнозування ризику розвитку третинного перитоніту / О. Б. Матвійчук // Шпитальна хірургія. Журнал імені Л. Я. Ковальчука. - № 3 (79). - 2017. - С. 24-29. 7. Re-evaluation of Mannheim prognostic index in perforative peritonitis: Prognostic role of advanced age. A prospective cohort study / A. Neri, D. Marrelli, M. Scheiterle [et al.] // International Journal of Surgery. - 2015. - Vol. 13. - P. 54-59.
2. Daniel, R. (2011). Surviving the first hours in sepsis: getting the basics right (an intensivist's perspective). Journal of Antimicrobials and Chemotherapy, 66 (2), 11-23.

3. Dani, T., Ramachandra, L., Nair, R., \& Sharma, D. (2015). Evaluation of prognosis in patients with perforation peritonitis 
using Mannheims peritonitis index. International Journal of Scientific and Research Publications, 5 (5), 1-35.

4. Kamble, R.S., Singh, M., \& Jaiswal, Y. (2016). Prognostic factors in perforative peritonitis: an observational study. International Surgical Journal, 3 (3), 1082-1092.

5. Kibe, S., Adams, K., \& Barlow, G. (2011). Diagnostic and prognostic biomarkers of sepsis in critical care. Journal of Antimicrobials and Chemotherapy, 66, 33-40.

Електронна адреса для листування: droniak@i.ua
6. Matviichuk, O.B. (2017). Prohnozuvannia ryzyku rozvytku tretynnoho perytonitu [Prediction of risk of development of tertiary peritonitis]. Shpytalna khirurhia - Hospital Surgery, 3 (79), $24-29$ [in Ukrainian].

7. Neri, A., Marrelli, D., Scheiterle, M., di Mare, G., Sforza, S., \& Roviello, F. (2015). Re-evaluation of Mannheim prognostic index in perforative peritonitis: Prognostic role of advanced age. A prospective cohort study. International Journal of Surgery, 13, 54-59.

Отримано 14.11.2019

\section{M. DRONIAK, I. M. SHEVCHUK, V. M. DRONIAK, O. YA. POPADYUK}

Ivano-Frankivsk National Medical University

\section{PREDICTION OF THE COURSE OF POSTOPERATIVE PERITONITIS}

The aim of the work: development of scale for predicting the risk of development of PP.

Materials and Methods. We analyzed 244 cases of postoperative peritonitis, operated in Surgery Department of Ivano-Frankivsk Regional hospital in 2010-2019. Concomitant diseases were detected in 176 (72.1\%) patients. The male gender was slightly more prevalent - 138 (56.6 \%). Patients' ages ranged from 18 to 88 years (median age 61 years). By the severity of the condition, the majority of patients (147 people (60.2 \%)) - within 1-4 days after surgery (median - 2 days) were in intensive care unit. Peritonitis was local in 125 (51.2 \%), diffuse - in 119 (48.8\%) patients. Postoperative complications developed in 74 cases (30.3 \%) and were purulent in 75 \%. Results and Discussion. Based on the results of our studies, to indicate the severity of postoperative peritonitis as predictors we offer the following indicators: age of the patient over 60 years, the number of leukocytes in the peripheral blood above $12 x 109 \mathrm{~g} / \mathrm{l}$, the level of C-reactive protein in the serum above $10 \mathrm{mg} / \mathrm{l}$, alkaline phosphatase activity of more than $1400 \mathrm{nmol} / \mathrm{l}$-s, diene conjugate content of more than 2.5 units of optical density, malonic dialdehyde content of more than $5 \mathrm{nmol} / \mathrm{ml}$, average molecular weight of more than 0.350 units. The value of CRP exceeding $5 \mathrm{mg} / \mathrm{l}$ is a bad prognostic sign, with 42 (30.9\%) of 136 patients with mild course of PP, and $98(90.7 \%)$ of 108 patients with severe one.

With positive four or more criteria there is a severe course of PP. Considering with results of researches, to determine the severity of postoperative peritonitis, we have proposed a working system for predicting the course of PP. Preliminary testing of this system confirmed its sensitivity $71.2 \%$ and specificity $81.4 \%$.

Key words: abdominal sepsis; postoperative peritonitis; prediction of a course.

\section{Н. Н. ДРОНЯК, И. М. ШЕВЧУК, В. Н. ДРОНЯК, О. Я. ПОПАДЮК}

Ивано-Франковский национальный медицинский университет

\section{ПРОГНОЗИРОВАНИЕ ТЕЧЕНИЯ ПОС.ЕОПЕРАЦИОННОГО ПЕРИТОНИТА}

Цель работы: отработать шкалу прогнозирования риска развития послеоперационного перитонита.

Материалы и методы. В статье проанализированы 244 случая послеоперационного перитонита, прооперированных в отделении хирургии Ивано-Франковской областной больницы в период 2010-2019 гг. Сопутствующие заболевания выявлены в 176 (72,1 \%) больных. Незначительно преобладали больше больные мужского пола - 138 (56,6 \%). Возраст пациентов был в пределах 18-88 лет (медиана - 61 г.). По тяжести состояния большинство больных (147 человек (60,2 \%)) - в течение $1-4$ суток после операции (медиана - 2 суток) находились в отделении реанимации и интенсивной терапии. Перитонит был местным ограниченным в 125 (51,2 \%), разлитым - в 119 (48,8 \%) больных. Послеоперационные осложнения развились в 74 случаях (30,3 \%) и были гнойно-септическими в $75 \%$.

Результаты исследований и их обсуждение. Судя по результатам наших исследований, для определения тяжести течения послеоперационного перитонита в качестве предикторов предлагаем следующие показатели: возраст больного старше 60 лет, количество лейкоцитов в периферической крови более 12х109 г/л, уровень С-реактивного белка в сыворотке крови более 10 мг/л, активность щелочной фосфатазы более 1400 нмоль/л-с, содержание диеновых конъюгат более 2,5 ед. оптической плотности, содержание малонового диальдегида более 5 нмоль/мл, уровень молекул средней массы более 0,350 усл. ед. Значение СРБ, превышающие 5 мг/л, является неблагоприятным прогностическим признаком, при легком течении ПП превышение этого уровня было в 42 (30,9 \%) из 136 больных, а при тяжелом - в 98 (90,7 \%) из 108 больных.

При положительных четырех и более критериям вероятно тяжелое течение ПП. Учитывая результаты проведенных исследований, для определения тяжести течения послеоперационного перитонита мы предложили рабочую систему прогнозирования течения ПП. Предварительная апробация этой системы показателей подтвердила ее чувствительность $71,2 \%$, а специфичность $81,4 \%$.

Ключевые слова: абдоминальный сепсис; послеоперационный перитонит; прогнозирование течения. 